\title{
Status, Prospects and Market Potentials of the Sea Cucumber Fisheries with Special Reference on Their Proper Utilization and Trade
}

\author{
M. Aminur Rahman ${ }^{1,2^{*}}$, Saddam Hossain Chowdhury ${ }^{2}$, Md. Jahidul Hasan ${ }^{3}$, \\ Md. Habibur Rahman ${ }^{1}$, Syeda Maksuda Yeasmin ${ }^{1}$, Nawshin Farjana ${ }^{1}$, \\ Md. Habibur Rahman Molla ${ }^{4}$ and Md. Shamim Parvez \\ ${ }^{1}$ Department of Fisheries and Marine Bioscience, Faculty of Biological Science and Technology, \\ Jashore University of Science and Technology, Jashore-7408, Bangladesh. \\ ${ }^{2}$ World Fisheries University Pilot Programme, Pukyong National University (PKNU), 365 Sinseon-ro, \\ Nam-gu, Busan-48547, Korea.
${ }^{3}$ Department of Fisheries, Fish Inspection and Quality Control, Matshaya Bhaban, Boyara, \\ Kingdom of Saudi Arabia. \\ ${ }^{5}$ Earth Solution Ltd., House \# 33, Road \# 4, Dhanmondi, Dhaka-1209, Bangladesh.
}

Authors' contributions

This work was carried out in collaboration among all authors. All authors read and approved the final manuscript.

Article Information

DOI: 10.9734/ARRB/2020/v35i730250

Editor(s):

(1) Dr. Ibrahim Farah, Jackson State University, United States of America. Reviewers:

(1) Kamila Foguesatto, Federal University of Rio Grande, Brazil.

(2) Poonam Singhal, St. Ann's College for Women, India. (3) Junianita Fridianova Sopamena, University of Pattimura, Indonesia. Complete Peer review History: http://www.sdiarticle4.com/review-history/59418

Review Article

Received 18 May 2020

Accepted 24 July 2020

Published 01 August 2020

\section{ABSTRACT}

Sea cucumbers belonging to the phylum Echinodermata are important marine invertebrates, generally occur in the sandy substrates and rocky shores near the bottom of sea. This review work has been attempted to make an interlink between biological and socio-economical perspectives of sea cucumber because of the high demand in the present world. The outer body part of sea 
cucumber (bêche-de-mer) has been recognized for producing secondary metabolites including vitamins and triterpenoid glycoside saponins that have profound ecological and bio-medicinal significance. Sea cucumbers are also used to remove arthritis pain, exert wound healing, and nowadays, are utilized in human health therapeutics and Asian folk medicine. Due to higher pharmaceutical, cosmeceutical and nutraceutical values, sea cucumber has become one of the most essential products, and fetched higher market prices and therefore, provide a significant earning source and employment opportunity to the coastal communities in many countries. The sea cucumber and its product have been considered to be the excellent bioresource in the invertebrate fishery, whose harvestings, transporting, handlings, processing and maintenance are easy, convenient and cost-effective. Historically, bêche-de-mer were harvested from the multi-species capture fishery and stored for long times for selling to the businessmen and traders directly on the site. As like other lucrative and expensive food items viz., fish-maws, shark-fins and abalones, sea cucumbers are taken into the account as the high-valued products in the world seafood markets. Nevertheless, bêche-de-mer product supply in the South-East Asian countries has been decreasing day by day because of unstrained harvesting and overexploitation. On the other hand, the marketing structure in these countries is typically ineffective and the trading networks are multifaceted. Due to the lack of proper information, fishermen are not usually getting proper values and actual prices from the sea cucumber products, whereas other distributors and value-chain members have made complex systems, which have led to high cost of the products. The sea cucumber products will still have higher possibility of trading throughout the world markets, that might eventually contribute to the global economy in a very worthwhile, significant and sustainable manner.

Keywords: Sea cucumbers; bêche-de-mer; status; prospects; potentials; utilization; trading.

\section{INTRODUCTION}

Sea cucumbers are economically important echinoderms, and thus making it one of the imperative sources of income and livelihood of millions of coastal communities in the world, especially in the Indo-Pacific island countries [1]. They are also popularized all over the world for the dried body-wall, viscera, or to create a dry product known as 'trepang' or 'bêche-de-mer' and alternative nutritional supplements that are extended to the eastern Asian markets [2]. The Indo-Pacific region is involved with trading of sea cucumber for more than one thousand years, principally for the clients of China [3]. Near about 66 species of cucumber animals are characteristically exploited in the world, with the largest quantities (47) from Philippines [4]. According to Toral-Granda et al. [5], around 70 countries are involved with fishing and trading of sea cucumber. Approximately $60 \%$ of sea cucumbers, dwelling in shallow tropical waters, connects with small scale fisheries [6]. According to Purcell [1], the fisheries contribution in export, regarding number of fishers $/ \mathrm{km}^{2}$ of reef, was the highest in Philippines (37.4) followed by Papua New Guinea (18.1) and Indonesia (15.9), respectively (during the temporary ban period), whereas in the Indian Sea and African fisheries, it was on an average of 1.7 fishers $/ \mathrm{km}^{2}$.
Increasing market demand, deficiency of alternate income source for fishermen, poor administrative and management measures, and inherent biological and ecological vulnerability of sea cucumbers have led to overexploitation of this important resource. Investigation showed an alarmingly high rate of overexploitation in addition to the consumption of sea cucumber, especially in the Indo-Pacific regions. Overall, $20 \%$ of sea cucumber fisheries has been depleted, $38 \%$ overexploited, $14 \%$ completely exploited and $27 \%$ underexploited or moderately exploited. About $27 \%$ sea cucumbers are taking illegally, regardless of countrywide bans. Purcell [1] stated that these unlawful fishing happen in the Western Indian Ocean and also in Central and South American Sea. According to ToralGranda et al. [5], the brown sea cucumber (Isostichopus fuscus), is the main species from the Ecuador, as of now recorded in CITES. Among the 377 species of sea cucumber investigated, the IUCN (International Union for Conservation of Nature) Red List has classified seven species as 'Endangered' or at high risk of extinction and nine species as 'Vulnerable' or at risk of extinction (www.iucnredist.org).

Worldwide sea cucumber fisheries have frequently lacked appropriate management plans and enforcement capacity to deal with unstrained exploitation [1], which is more apparent over the Indo-Pacific region. The national sea cucumber 
fisheries of the Indian Ocean have been existed in various countries for a long time [7], but the organizational capacity with regards to management is weak [8]. The principal goal for the management of sea cucumber fisheries would be to look after the reproductive capacity of brood stocks with the aim that the resources are accessible to who and what is to come [4]. The enforcement capacity varied significantly among fisheries and would in general be weak in tropical region fisheries with low-income countries. It has been documented that the overexploited and depleted sea cucumber fisheries tended to have very less regulatory strategies than the better performing fisheries [1] and this is emphasized to have multiple management strategies, which are easily understood, applied, enforced and implemented [9]. Whatever the case may be, the worldwide production of sea cucumber has not depleted in light of the fact that there are still obtainable supplies, aquaculture production, limited awareness of biodiversity conservation, and insufficient management and regulatory measures [10]. It is assumed that the resilience of the sea cucumber fisheries will be possible if the fishers are taking part in the management system and also can adjust to the changes occurred in the aquatic resources $[11,12]$.

Since 1962, the ICAR (Indian Council of Agriculture Research) has made significant contributions towards the conservation of sea cucumbers through a number of projects [13]. The ICAR has conducted research on taxonomy, biology, ecology, zoogeography, toxicity, parasites, environment, and captive breeding and culturing of sea cucumbers $[14,15,16]$. The CMFRI (Central Marine Fisheries Research Institute) of ICAR had increased the production of quality seeds of the economically important species, Holothuria scbra (one of the high-valued sea cucumber species all over the world) in 1988 due to high market demand and delicate taste qualities [17], and organized a workshop on the basis of national need of sea cucumber in 1989 . In 1992, the committee organized another programme for fishermen to train them on the appropriate technique to handle sea cucumber from catching to selling and processing with low price, for their large benefit [18]. Sea cucumber aquaculture has also been started to establish since 2001 through the financial help of various organizations, while culturing the most popular and commercially important species, $H$. spinifera [19]. In order to undertake effective management measures by fishers, buyers, academicians and researchers, this organization has urgently published and distributed more than 250 research papers, 4 special publications and few handouts, which are closely associated to the overexploitation of sea cucumber species.

The supply, demand and price are the key components of marketing system, however the problem occurs while the analysis of supply contains an assortment of concerns from the collection of sea cucumber products to transportation, processing and finally distribution. Moreover, supply could not only be considered on the basis of quantity but emphasis should be given on the quality [22]. Likewise, analysis of demand covers a prevalent range of interests. Among them, the features of demands, the quality of demanded products, exact requirement of products, and the trends in volume resulting from changes in choices and tastes are particularly important. Prices should be viewed on the basis of the interactions between supply and demand. Besides, essential issues should need to be implemented on evaluations of standard and grade, for example, the use of 'good manufacturing practices' and 'hazard analysis critical control point' approaches [22]. On the other hand, due to the increasing global demand, the new sea cucumber products are in the state of fascinating advancements [22]. Certainly, demand and supply issues might not be looked separately. Accordingly, sea cucumber could contribute to the national economy through the creation of employment and export earnings [22]. However, a good number of works on the biology, ecology, biodiversity, reproduction, aquaculture and conservation of sea cucumbers have been done but a very few studies have been conducted on the economic aspects such as product development, marketing, trade and business. Considering the high international demands as well as high nutritional and commercial values, the present work has been conducted to assess the status, prospects, potentials and importance of sea cucumber fisheries in the Indo-Pacific countries, and to investigate the marketing opportunities and challenges with special emphasis on their proper utilization and trade.

\section{METHODOLOGY}

A comprehensive literature reviews as well as relevant information/data using electronic databases on sea cucumber fisheries from different aspects were investigated. The study also provided a synthesis of outcomes and 
discussions from the available published papers on sea cucumbers. In the first part, emphasis was given on the collection of relevant published information and data on marketing features from South and East Asia. The second part discussed about the product promoting, marketing opportunities as well as difficulties in enhancing sea cucumber production throughout the region. The third part gave a synthesis of common marketing matters, and also offered a set of recommendations on the most appropriate methods to investigate the odds, overcome the difficulties, and manage the different issues perturbing the sea cucumber industry in the area.

We incorporated a wide range of relevant investigations like journal articles, reports, books and book chapters with respect to our subject of the study. Also the necessary information and need-based data were collected through the online investigations as well as asking relevant questions to the sea cucumber stakeholders. At first, we read all the paper abstracts to judge the suitability of the study and after that all the appropriate references were added to the list of articles. Next, we retrieved and saved the full texts of the selected references. Additional knowledge and updated information were also gathered on the subject matter from the library database and interlibrary lending. In total, 92 published articles were evaluated, of which 65 articles were finally utilized in this paper. All the relevant articles were cited in each section of the text (where necessary) as well as listed accordingly in the reference section. The articles which were not relevant with the present work and not composed in English, were finally discarded.

\section{RESULTS AND DISCUSSION}

\subsection{An Outline of Sea Cucumber Trade}

Sea cucumbers belonging to the phylum Echinodermata, are the members of the larger group of marine invertebrates under the class Holothuroidea, and are related to the sea urchins, sea stars, basket stars and brittle stars. They have the characteristic leathery skin and an elongated body containing a single and branched gonad mass. Sea cucumbers are found on the seafloor worldwide. A total of 1200 sea cucumber species were identified in the world among which 49 species were found in New Zealand waters [20]. The production of world sea cucumber increased from 130,000 tons in 1995 to 411,878 tons in 2014 [21,22]. Worldwide, this fishery supplies crude sea cucumber from bases to the several regions of the world aimed at handling into bêche-de-mer. During the period of nineteen centuries, a growing increase in the interest for large sea cucumber combined with a decrease in supply, encouraged the investigation into the fishery of the commercial species [23]. This reclassified the global limits of the bêche-de-mer business and diverted some enthusiasms from the typical species (primarily tropical or antiquated northern fisheries), to the exploration of new, formerly unutilized, tropical and calm types such as Stichopus californicus and $S$. parvimensis on the Washington coast, and Cumumaria frondosa on the East coast of Canada [3]. A widespread sea cucumber fishery off the Queensland coast and the Torres Strait region in Australia has a TAC (total allowable catch) of 500 tons every year. As one species is focused on and fished out, other species are searched for, with the end results being the overexploitation of sea cucumbers. Currently, the major species being focused on the black teatfish (Holothurian nobilis). However, attention is increasing towards the harvesting of the white teatfish (Actinopyga echinites), because the black teatfish have been fished out [22].

\subsection{Importance of Sea Cucumbers}

\subsubsection{Commercial valuation of sea cucumbers}

Around 60 species of sea cucumbers are commercially harvested over 70 countries in the world. In spite of the fact that despite the market value of this harvest varies from species to species, sea cucumber fisheries advocate to an essential part of costal livelihoods and provide jobs to approximately three million fishers around the world [24,25]. The Indo-Pacific region is considered to be the most suitable habitat for the commercial production of sea cucumbers. Based on the import data to Hong Kong, the region represented one of the main five sea cucumber producing countries somewhere in the range between 1996 and 2011. However, the production volumes of sea cucumbers in several countries (viz., Japan, Indonesia, Philippines, Fiji, Papua New Guinea) have been declining due to over-exploitation and lack of appropriate conservation strategies [1,24]. Sea cucumber fisheries around the Pacific region, represent the third-most commercially valued marine export product, following tuna fishery and pearls, having a yearly trade value of $20-50$ million US dollar $[1,24]$. 
The body of sea cucumber is mostly traded in dried bêche-de-mer from, which consists of $99 \%$ of all worldwide sea cucumber trade [26]. Once rehydrated, this product is enthusiastically consumed for its therapeutic advantages and encompasses one of the five important luxury commodities in Chinese festive meals for serving in special occasions, such as for the Chinese New Year celebration [27,28]. The present advancement of Chinese markets has caused an emerging expansion of these fisheries $[10,26]$.

Hong Kong (HK) has long been considered the center of bêche-de-mer imports, marketing and trade. Nonetheless, in the previous ten years, the development of other trading center has caused a decrease in its relative market piece. These include Singapore, Taiwan, Japan and Korea [28]. Approximately, $80 \%$ of bêche-de-mer from HK is re-traded, $90 \%$ of which is predestined for China [29]. In 2007, HK imported a total of 5,296 tons of dried sea cucumbers from 58 countries. These sea cucumbers were then re-exported to 13 countries, including China [30].

\subsubsection{Nutritional importance}

Sea cucumbers are economically important for their nutritional and pharmaceutical properties. A good number of species are also harvested for ornamental purposes [31]. In the business perspective, prices of sea cucumbers are fixed on the basis of size, shape, color, appurtenance, taste, demand and market values. In Korea and Japan, the cleaned body walls of the sea cucumbers are eaten raw or pickled, and the particular parts are consumed from the respiratory organs, gonadal tissues and guts [32]. As of nutritional perspectives, sea cucumbers are very rich in essential protein and lower fat contents, and also have an impressive profile of nutritional supplements, viz., Vitamins $A, B_{1}$ (thiamine), $\quad B_{2}$ (riboflavin), $B_{3}$ (niacin), and important amino acids, trace metals and minerals, particularly calcium, magnesium, iron and zinc $[21,22,33,34,35]$. However, the higher protein along with lower fat contents make sea cucumber perfect for peoples who are suffering from blood pressure.

\subsubsection{Medicinal importance}

Along with health and nutritional benefits, sea cucumbers have long time been considered as the traditional medicine for the peoples of Asian countries. Historically, the Chinese peoples utilized sea cucumbers for the treatments of physical weakness, malnutrition, constipation, intestinal dryness, kidney disorders and frequent urinations Latest researches have shown that sea cucumbers are very rich in valuable bioactive compounds with wound healing, antiangiogenic, anticancer, anticoagulant, antihypertension, antiinflammatory, antimicrobial, antioxidant, antithrombotic, antitumor and antidiabetic properties $[21,33,34,35,36,37]$. They also contain higher amounts of mucopolysaccharides, such as chondroitin sulfate, which is recognized for diminishing arthritis pain and suppress viruses like herpes and is familiar for the HIV therapy $[33,34,35,37]$. Considering the biomedical potential, the modern pharmaceutical and food companies are very much interested to produce nutraceutical products and functional foods using various parts of the body from sea cucumbers $[21,34,35]$. Currently, sea cucumbers are also being used for important commercial products such as body lotion, balm, moisturizer, soap, toothpaste, face wash gel, juice etc. $[33,38]$ as well as some other branded items, viz., Arthi Sea, Sea CuMax (arthritis pain relief drug) and Sea Jerky. Because of these nutritional and therapeutic health benefits, sea cucumbers are considered as one of the promising area of biomedical research [39].

\subsubsection{Ecological importance}

Due to the omnivorous nature, suspension feeder and predominantly detritivores, sea cucumbers play a significant role in cleaning the sea floor by consuming the decomposed materials and thus maintain the suitable aquatic habitat for the growth and production of other bottom-dwelling marine organisms such as corals, sea urchins, bivalves, etc. As suspension and bottom feeders, they also maintain excellent seawater quality through influencing the carbonate content and $\mathrm{pH}$ of water [40]. They also support $\mathrm{CaCO}_{3}$ to the coral reefs and act like a characteristic natural antacid to buffer the acidic environment and also help in the recycling of suspended matters [41]. Sea cucumbers also help in breaking down organic matters and rearrange the nutrients to the marine water column and by this way prevent hypoxia and other harmful materials going down into the bottom sediments. Once they ingest sands, the normal digestive processes in the gut of sea cucumbers enhance the $\mathrm{pH}$ of water on the reef where they excrete, disputing the adverse impacts of sea acidification. The ammonia waste produced when sea cucumbers digest sand also serves to fertilize the encompassing areas, 
delivering nutrients for coral growth and development, and turnover of benthic diatom communities [42]. Therefore, the overexploitation of sea cucumbers might lead to deleterious impacts on the marine bottom ecosystem $[28,43]$.

\subsubsection{Economic importance}

Within the period of imposing ban, sea cucumbers were typically harvested by snorkeling, shallow-water diving as well as taken as by-catch from trawling. Harvesting by skindiving was commercially most effective than different methods of fishing as the expense of investment and operation were comparatively low. Nevertheless, the income was five times higher than the operational expenses throughout the pre-ban period, which was lessened to about 3.0 times in the ban time, meanwhile fishermen were getting less prices during the ban (prohibition) period. In addition, the majority of the fishermen were selling freshly-caught sea cucumbers during the period of prohibition, within which they get comparatively low price [44].

\subsection{Sea Cucumber Fishery and Resource Status}

\subsubsection{Sea cucumber fishery}

Sea cucumber fisheries in the sub-tropical and tropical regions of the Western Pacific are usually multispecies compared to the tropical species in the Indian Ocean (Holothuria scabra), Eastern Pacific (Isostichopus fuscus) and Caribbean (Astichopus multifidus, Holothuria mexicana and Isostichopus badionotus). Across the Western Pacific, sea cucumbers are predominantly deposit-feeding shallow water (up to a depth of $50 \mathrm{~m}$ ) holothurians under 2 families and 8 genera such as Holothuridae (Holothuria, Actinopyga, Bohadschia and Microthele) and Stichopodidae (Stichopus, Isostichopus, Parastichopus and Thelenota). In temperate areas, 1 or 2 species of sea cucumbers are found in the Western Pacific around Russia, Japan, China and Korea (Stichopus japonicus), Southern Hemisphere off New Zealand (S. moli), Eastern Pacific Coast of North America (Parastichopus californicus and P. parvimensis) and Western Atlantic Coast of North America (Cucumaria frondosa) [45].

The size range of sea cucumbers between $5 \mathrm{~cm}$ and $1 \mathrm{~m}$, are considered for 'bêche-de-mer' production [46]. They are usually found in the aquatic marine ecosystem such as reef flat and grass beds. Typically, sea cucumbers are harvested in the tropics by small bottom-trawl nets (viz., beam-trawl nets, roller-pulling nets, scallop-drag gears etc.) used mostly on the softbottom habitats; collection directly by hand at low tide, or collection from the shallow water grass beds, reef flats and mangrove lagoons; collection by hand using snorkel, SCUBA (self-contained underwater breathing apparatus) diving gear and lift bag nets in the deeper lagoon and reef ecosystems; and collection with snorkeling, wading of using underwater lights and torches at night [47].

Sea cucumbers are vital resources for coastal livelihoods and shoreline ecosystems. Most of the Asian markets are involved in harvesting, processing and trading sea cucumbers consisting of at least 60 species from 40 countries [47]. The retail prices of dried 'bêchede-mer' are within the range from USD 300 to 500 per $\mathrm{kg}$. Sea cucumber fisheries are divided by scale of stock, management and fishing activities. In recent years, the sea cucumber stocks have been depleted due to overfishing and unstrained harvesting. Some management measures have been taken by the government of developing countries for some fisheries but most of them are still overexploited. Improved knowledge on sea cucumber fisheries is a vital prerequisite for management. Government should take strict decisions and intensive measures as well as provide alternative income sources to the fishers and impose enforcement (when necessary) for proper management, utilization and conservation towards sustaining the sea cucumber populations for present and future generations [9].

\subsubsection{Growth of sea cucumber fisheries}

Harvesting and sun drying of sea cucumbers to produce the dried body mass (bêche-de-mer), had begun in the Asia-Pacific region more than 300 years ago [7]. The Chinese higher society sought this product for their medical advantages and health benefits [48]. The advancement of the trade followed the marine bioresource exploration and extension at the time with marketing agents living regional trading outposts channel ling trade from far areas to China [32]. Assisted by the simple drying technique required to conserve the product, and the high economic value, the trade with sea cucumbers extended until the early 1900s, when the fishery declined and remained to a great extent inactive during the world wars and China's marginalization in 
global trades [49]. Nevertheless, in the early 1960s, the sea cucumber trade regained a portion of its significance and with reform of China's outside market approach and joining into the world economy during the 1980s, the market for sea cucumber extended quickly into formerly unfished regions [50].

Currently, it has been assessed that more than 3 million peoples around the globe attend in various sorts of sea cucumber fisheries targeting $>60$ species on all continents, largely to produce bêche-de-mer for the seafood market in China [4]. In the tropics, sea cucumbers are usually sourced from near-shore regions using simple and easy harvesting techniques like gleaning or breath-hold jumping, making this bioresource accessible to a wide portion of the fishing communities. The sea cucumber fishery has historically driven remote rural economies [51] and during the course of improvement, it has given the ways and means of income in marginal and poor areas [52], and even help in the affected zones to recover. Sea cucumbers are a portion of the world's most high-valued marine products and in some Pacific islands, the exportearnings from sea cucumbers have outperformed that of finfishes and other marine bioresources [4], showing high value of the product and significance to the local economy.

\subsection{Susceptibility, Occupation and Socio- Economic Relevance}

\subsubsection{Global over-exploitation susceptibility of sea cucumbers}

and

The simple collecting method and least effort during handling has increased the sea cucumber fishing and trading in the Indo-Pacific regions. Insufficient management measures, anthropogenic catastrophes as well as overfishing of commercial species make the extreme changes and severe depletion of sea cucumber population that highly impacts on the global economy and trade [53,54]. Basically, harvesters can easily and successfully catch the shallow water holothurians from their natural habitats, which might primarily cause the sea cucumber population to become vulnerable to overexploitation [55]. Majority of the tropical sea cucumber species usually inhabits in shallow seawaters within the edge of breath-hold diving [50]. Due to the sessile mode of nature, sea cucumbers are unable to escape rapidly from patches of high thickness and once identified, they are easily and subsequently caught by the fishers. Furthermore, soon after the embryonic and larval phase, slow growth rate of juveniles and adults, longer times to get maturity, benthic life span and low rates of recruitment make a few animal groups (including sea cucumbers) vulnerable towards overfishing and thus hinders the restoration of depleted population.

\subsubsection{Global trades of sea cucumbers}

During 1917-1986, the global bêche-de-mer market statistics were reviewed [7]. In the beginning, the Chinese had controlled the market and also traded sea cucumbers to a larger extent with Sri Lanka and South India. Export data of bêche-de-mer are available from 1898 onwards from the Madras Presidency. The trade has shifted to two central markets (which are also considered as the main re-exporting centers) such as Singapore and Hong Kong. Indonesia, Philippines, Japan, Fiji Islands, Papua New Guinea, Madagascar, Thailand, USA and Solomon Islands [7,22]. Fig. 1 shows the trend in the export of bêche-de-mer from India during 1992 to 2014. The amount of prices per $\mathrm{kg}$ stood at approximately zero in 1992 and steadily rose to Rs. 10 by 1997 and then more sharply to Rs. 400 in 2005 . At this point, the prices per $\mathrm{kg}$ were increased until Rs. 60 before touching the highest level of Rs. 140 per kg by 2014. Due to imposing ban, export of bêche-de-mer endured a serious obstruction in 2009 and declined to 37.14 $\mathrm{t}$ from $47.84 \mathrm{t}$ in 2008 (Fig. 1) [13].

Sea cucumber were usually banned by their size in the off seasons. As the main portion of the exports was maintained on the basis of size grades between 2" and 3", the exporters of bêche-de-mer were suffered remarkably during the harvesting season and therefore they claimed the exclusion of ban, which ultimately caused the overexploitation of sea cucumbers in their natural stocks. During that time, no nation had limited the body size for export and therefore different nations were exporting size underneath 3". From the examinations of commercial invoices of exports for the period from 2006-2007 to 2010-2011, it has been observed that the size categories beneath 3" represented for 49 to $87 \%$ (Fig. 2) [13]. During the fiscal year 2010 to 2014, the exports grabbed because of the additional work put by the traders to get material from different places because of the higher cost offered (Rs. 86 to 148 for every kg) of bêche-demer.

The export figures from 2009-2010 to 2016-2017 shows a gradual decline to $11 \mathrm{t}$ from $123 \mathrm{t}$ in 
2009-2010 (Fig. 3). The export value increased from 2009-2010 to 2012-2013 with a regular price of Rs. 275.5 per $\mathrm{kg}$ but during 2016-2017 the mean price was increased (Rs. 567.0 per kg [13].

\subsubsection{Changing livelihood patterns of fishers during fishing at ban period}

Around twenty thousand people were engaged with sea cucumber fishery and more than fifty thousand were profited from this fishery in the Gulf of Mannar and Palk [56]. In 1982, the ban on the export of the processed sea cucumbers of under 3" size partly affected the livelihood of fishers. Nevertheless, the 2001 blanket ban completely affected the livelihood of thousands of fishers' families associated with sea cucumber fishing. There was a loss in their normal pay as they were not ready to do other fishing exercises because of lack of capacity for investment. As a result, their debts increased and they were not able to give quality instruction to their youths. They were also encountered with troubles in arranging marriages of their daughters. A couple of fishers moved to different areas and states in searching for occupation after imposing the ban [44]. Disadvantaged fishers and traders of this area made a few representations to the Ministry of Environment, Forests and Climate Change, Government of India, requesting to withdraw the ban and to permit fishers to harvest sea cucumber from the region.

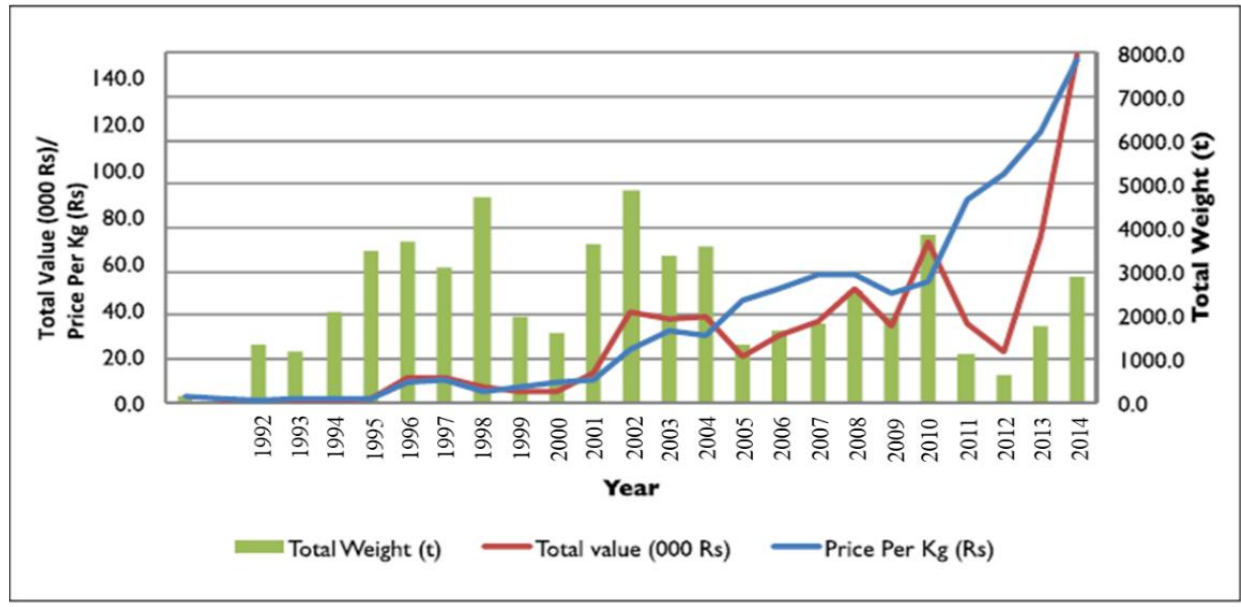

Fig. 1. Trends in the export of Bêche-de-Mer from India during 1992 to 2014 [13]

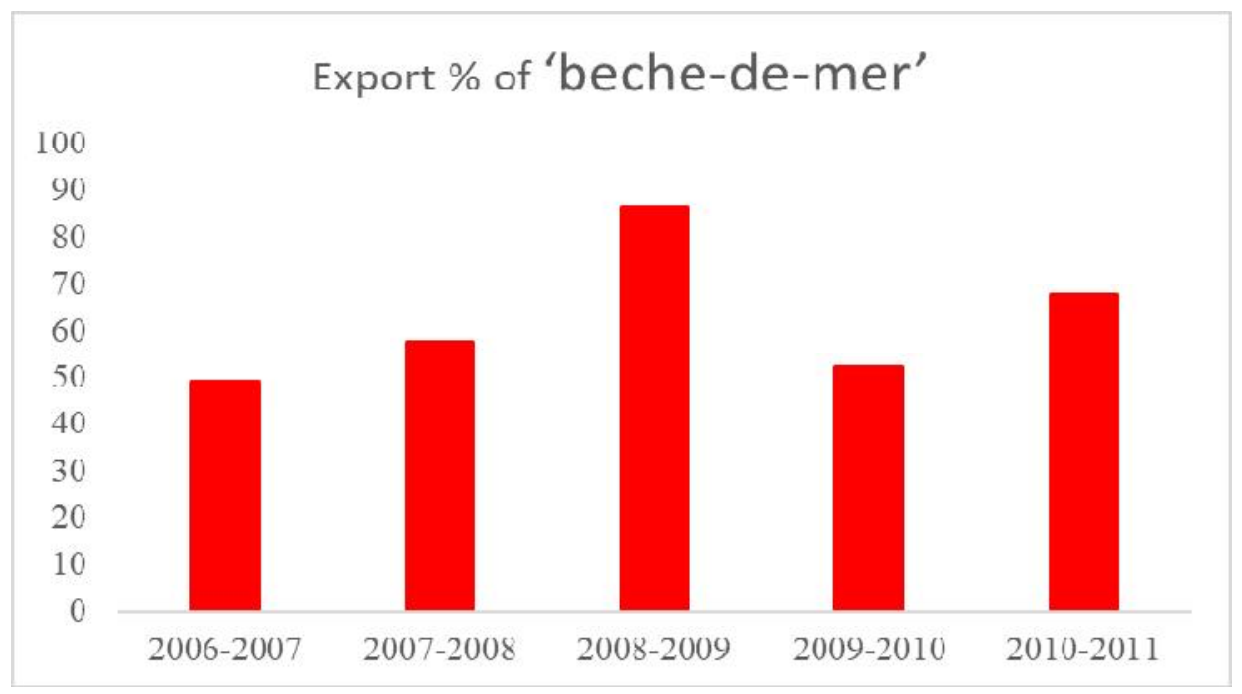

Fig. 2. Percent export of Bêche-de-Mer < 3" size from India [13] 


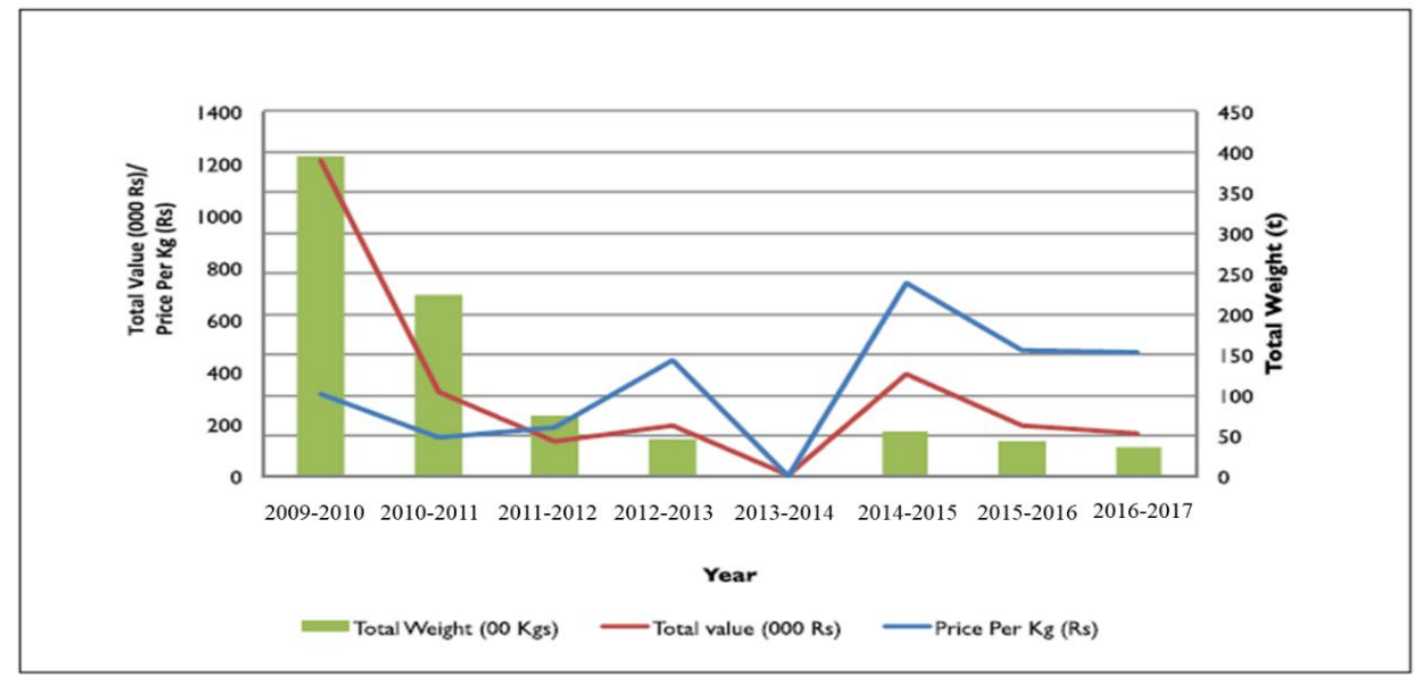

Fig. 3. Trends in the export of 'Bêche-de-Mer' from India during 2009-2010 to 2016-2017

As there was no positive reaction from the Ministry, the fishers and traders have currently moved for the legal action. As the ban has affected a large number of fishers' families, they need the ban to be lifted at any rate for a couple of economically important species. They have agreed to follow administrative measures like size limitation on fishing of undersized sea cucumbers, prohibition of broodstocks from fishing, preventing the uses of damaging fishing gears, restrictive fishing ban period for stock enhancement, sea farming and stock improvement programs.

\subsubsection{Economic aspects}

Throughout the ban time, the sea cucumbers in most cases were harvested by skin-diving as well as collected as trawling by-catch. Catching of sea cucumbers by skin-diving was commercially most proficient method than others due to lower operation and investment expenses. Nevertheless, the revenue was five times more than the operating expenses during the pre-ban time, which has decreased to 3.3 times in the ban time, since fishers are getting reduced prices at the ban period. In addition, the greater part of the fishers was selling freshly-caught sea cucumbers during ban for which they get less prices [44].

Over the recent fifteen years of ban, the price of sea cucumbers had increased 2 folds in each level of the supply chain. The increase in prices happened because of the increasing demands in the global markets. The market price of bigger sea cucumbers was usually 2.0-2.5 times higher than the smaller ones (Table 1). The fishers obtained around half of the value of sea cucumbers before and during the ban time. The maximum benefit was obtained by the exporters, who sold their bêche-de-mer products usually for Rs. 10,500 by investing just Rs. 6,200, i.e., a benefit of about $69 \%$ over the expenses incurred (Table 1). Furthermore, during the ban, the net benefit (\% over total expenses) was dispersed equally along the market chain. The reasons behind this might be due to the panic that all are engaged in illegal exercises and would prefer not to be uncovered. However, the traders were not ready to give the export-price to the fishers/middlemen before and after imposing the ban.

\subsubsection{Key features of marketing system for sea cucumber in South-East Asia}

In South-East Asia, the key frameworks for sea cucumber marketing are mainly depended on the supply, demand and price. Supply comprises of collections from the wild and production from lakes, reservoirs, ponds etc. All activities associated with preparing, processing, distributing and marketing of bêche-de-mer products accessible to customers are also found in the published paper of Perez and Brown [57] as a major part of supply. Demand is evaluated on the basis of the utility derived in consumption, and its spatial and temporal natures. The marketing networks as well as the price of the bêche-de-mer products are limited to investigate of premium price for quality, value spreads and value patterns. 
Table 1. Mean regular market price for processed sea cucumbers across the supply chain in 2015 [44]

\begin{tabular}{lllll}
\hline \multirow{2}{*}{ Actors in supply chain } & \multicolumn{2}{c}{ Before ban (Rs. per $\mathbf{~ g )}$} & \multicolumn{2}{c}{ After ban (Rs. per $\mathbf{~ g})$} \\
\cline { 2 - 5 } & $\mathbf{2 0}$ counts & $\mathbf{4 5}$ counts & $\mathbf{2 0}$ counts & $\mathbf{4 5}$ counts \\
\hline Fishermen & 5,000 & 2,000 & 9,000 & 3,000 \\
$1^{\text {st }}$ level Middlemen & 5,100 & 2,100 & 9,600 & 3,500 \\
$2^{\text {nd }}$ level Middlemen & 5,300 & 2,250 & 10,400 & 4,100 \\
$3^{\text {rd }}$ level Middlemen & 5,600 & 2,500 & 11,800 & 5,000 \\
Traders & 6,200 & 3,400 & 15,000 & 7,000 \\
Exporters & 10,500 & 5,000 & 18,000 & 11,400 \\
\hline
\end{tabular}

\subsubsection{Supply-related marketing system characteristics}

There are various ongoing networks that keep running across South-East Asian countries with regards to market-related supply framework for bêche-de-mer products. Majority of the nations in the region are the main sources of sea cucumber products, and the species profiles are pretty much since the countries have a similar tropical weather. Harvesting of sea cucumbers from the wild is more or less minimal, and usually conducted by low-wage families inhabiting near the coasts. Initial handling method is traditional and the later processing systems are similar over the area. Overexploitation of commercially important species is a typical issue, with each individual country taking particular activities to address the issue. At the long last, all countries are involved in investigating and exploring the sea cucumber aquaculture as an important supply source to enhance the incomes of the coastal households and reduce the unstrained exploitation in nature [58].

\subsubsection{Marketing distribution system}

Production of sea cucumber in South-East Asia is for both domestic utilization and the international export markets [59]. Be that as it may, the variations between the local and export market depends upon the countries from where it came from. Countries with little demand such as the Philippines, Indonesia and Cambodia [60], where the greater part of production is exported and other utilizations (e.g., consumption) is limited to local Chinese inhabitants. Notable local markets exist in Vietnam and Malaysia. The overall sea cucumber market flow involves fishers, local collectors and processors, other traders in the source locations, and exporters located usually in larger towns and cities (Fig. 4).

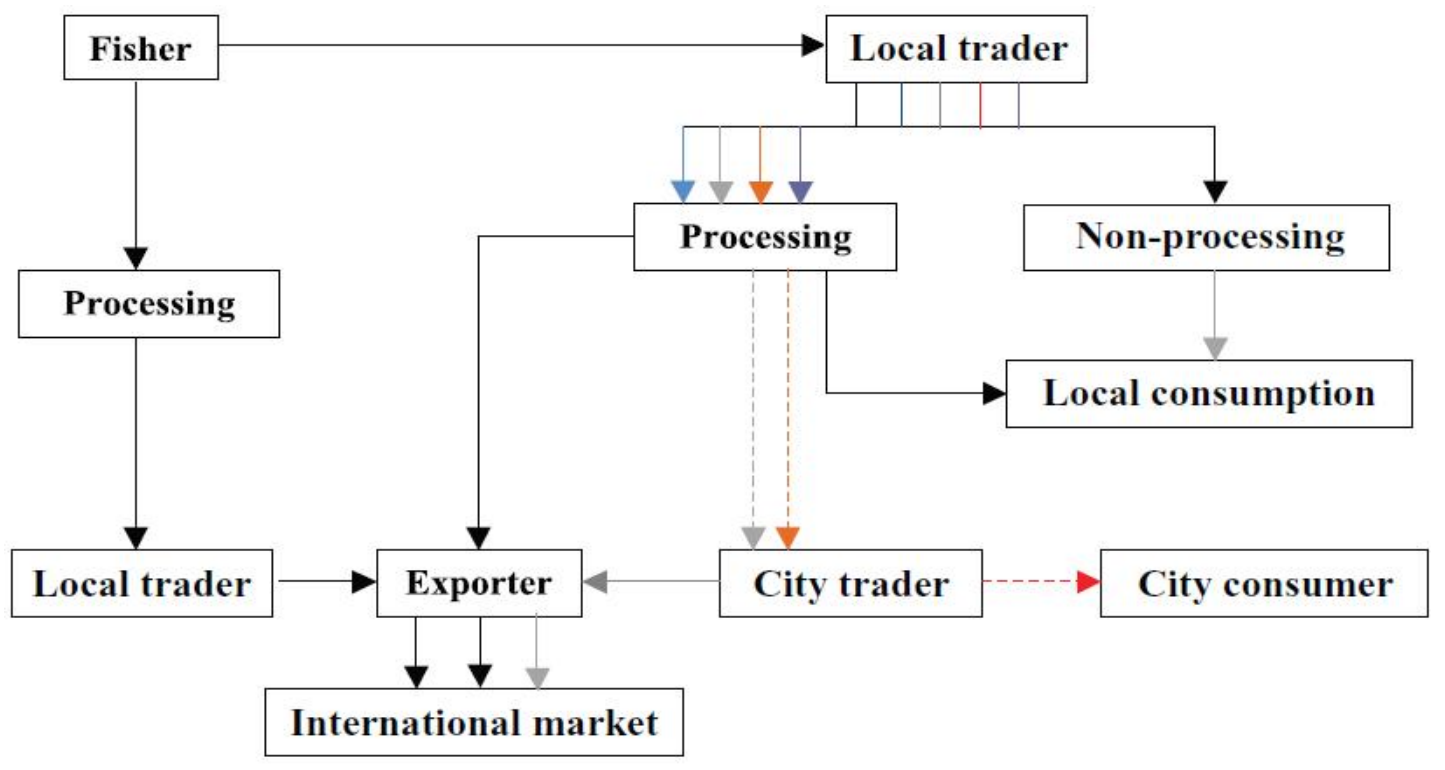

Fig. 4. Marketing system of sea cucumber from fisher to international market [59] 
Firstly, fisher harvest sea cucumbers and sell (either in fresh or dried form) to local buyers/traders (who also purchased directly from fishermen) with an option to dry by themselves. Both the village-level collectors and field-based processors are existed in the harvesting areas. Local traders are selling in two ways such as local trader to exporter or after processing to city trader than exporter. Finally, after collecting of all products from local traders, exporters then sell it to the International market (Fig. 5). The domestic markets of Malaysia sell sea cucumbers to the local processors for manufacturing conventional medicines and other products associated with the health benefits [61]. Nevertheless, a main portion of sea cucumber in Malaysia is exported for international market.

\subsubsection{Marketing system related with demand}

Among the Asian countries, demands for sea cucumbers are mainly raised from the higher and middle classes, particularly in China and Japan. Traditional understanding on sea cucumber as biomedicine has been prescribed for minor injuries (e.g., crude cuvirian tubule of sea cucumber used as crude plaster for minor wounds healing). Sea cucumber extracts are also utilized for the treatments of tumors, parasitic diseases, hypertension, high blood pressure, cardiovascular diseases, arthritis pains, kidney disorders, joint inflammation and so on $[21,22,33,34,35,36,37,63] . \quad$ In international business perspectives, Hong Kong represents the main global market followed by that of Singapore. Instead, for the most cases, Hong Kong re-exports bêche-de-mer to China. The sea cucumber product types, volumes and values for world trade are presented in Table 2. The world trade with sea cucumber products keeps on expanding as the price for the product increases through time, being the Chinese population comprising the main customers.

A remarkable feature of sea cucumber market in Hong Kong is the rising of medicine and herb shops where different types of sea cucumbers and their bêche-de-mer products are kept and demonstrated in large transparent glass/plastic jars for selling (Fig. 6 and Fig. 7). The commercially important species of tropical sea cucumbers such as Holothuria fuscogilva, $\mathrm{H}$. scabra, H. whitmei, Actinopyga lecanora and Thelenota ananas are usually displayed in these shops, the sell prices of which varies significantly from $\mathrm{HK} \$ 1,300$ to $\mathrm{HK} \$ 1,600$ considering the reported sell between 6 and $7 \mathrm{~kg}$ per day.

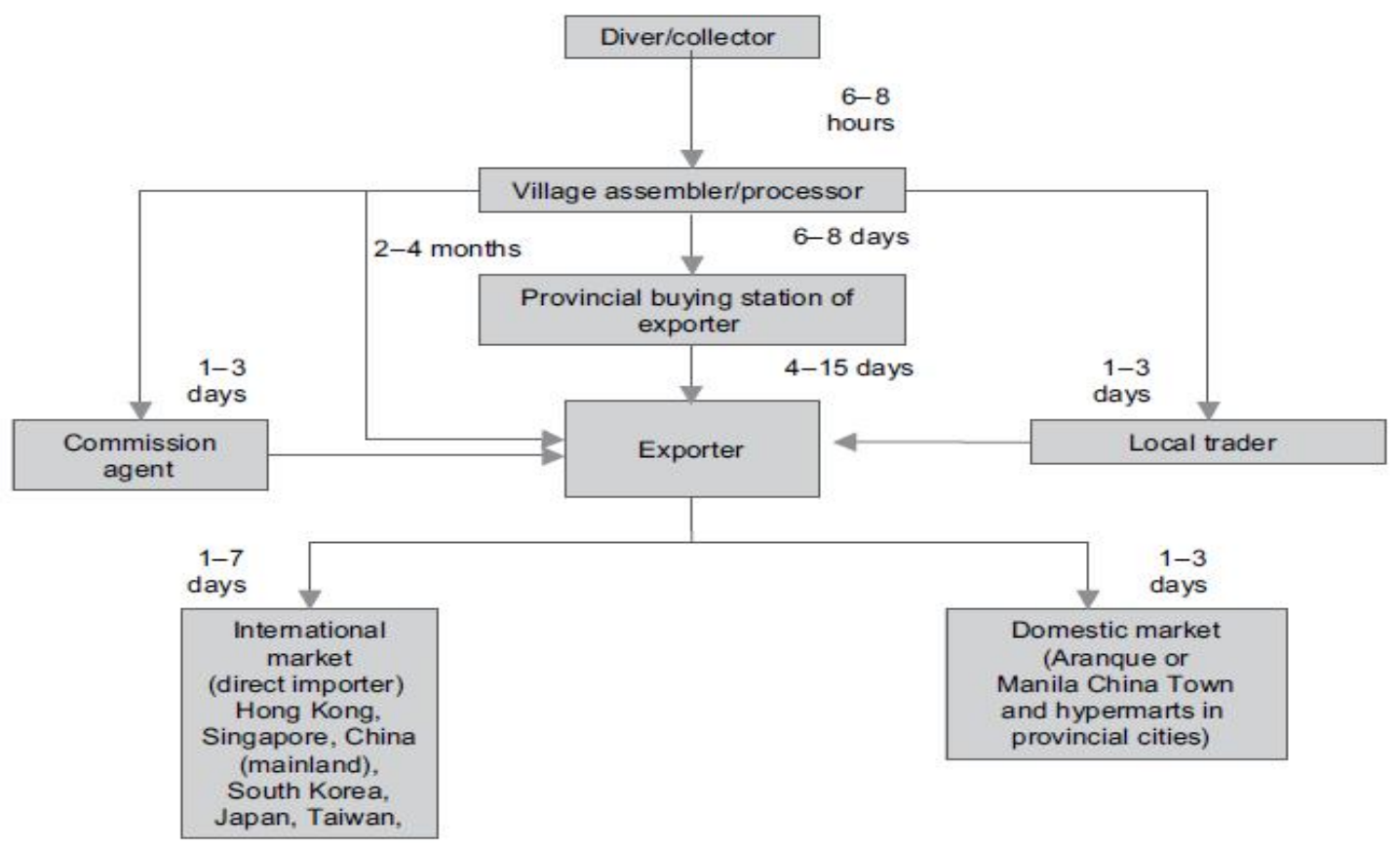

Fig. 5. Key steps of sea cucumber product flow from primary to tertiary level [62] 
Table 2. Sea cucumber trades over the world

\begin{tabular}{llll}
\hline Product features & \multicolumn{3}{c}{ Year } \\
\cline { 2 - 4 } & $\mathbf{2 0 1 3}$ & $\mathbf{2 0 1 4}$ & $\mathbf{2 0 1 5}$ \\
\hline Fresh, live and freeze (weight in million tons) & 56 & 34 & 67 \\
Price (US dollar in thousands) & 369 & 388 & 417 \\
Dry and brine products (weight in million tons) & 6,463 & 4883 & 5,734 \\
Total price (US dollar in thousands) & 44,215 & 42,021 & 55,852 \\
\hline
\end{tabular}

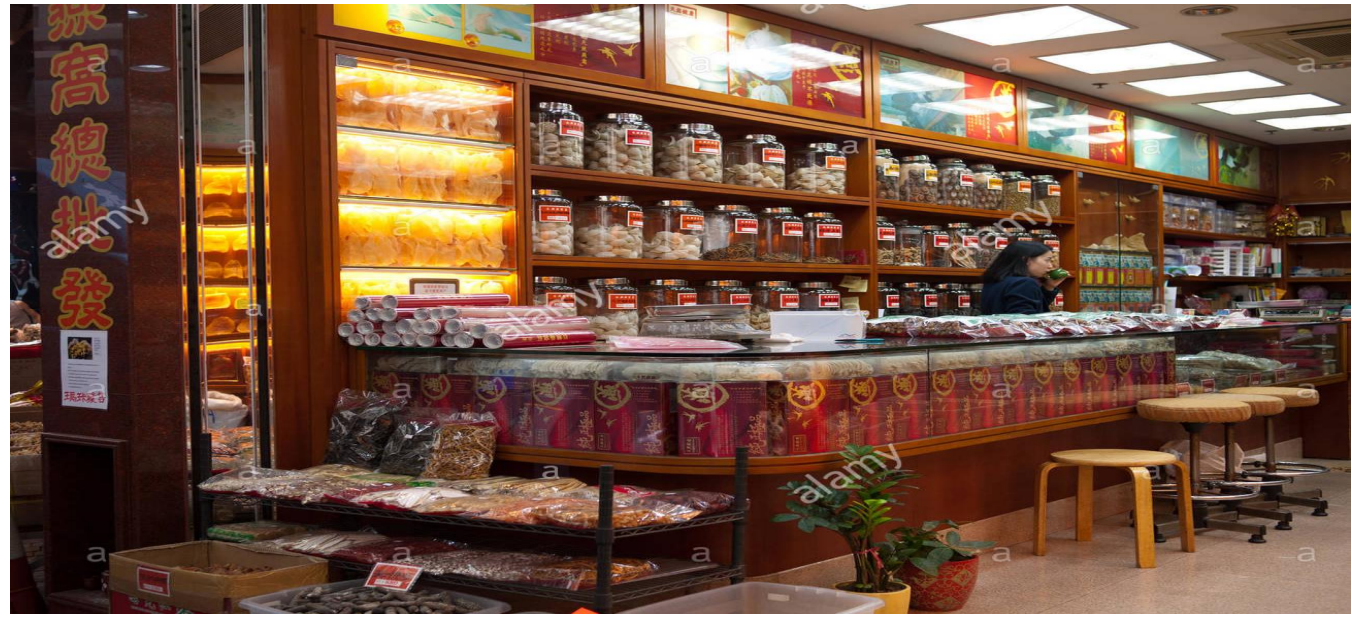

Fig. 6. Herb and medicine store of sea cucumber in Hong Kong

Generally, sea cucumber market in Hong Kong, could be described as having:

- a great inclination for certain species, among which Apostichopus japonicus is considered as the most lucrative species, and is retailed up to $\mathrm{HK} \$ 58,000 / 600 \mathrm{~g}$ in the medicine and herb shops. Other species such as Holothuria fuscogilva, $H$. scabra $H$. attra, $H$. whitmaei and $T$. ananas are also considered to be high-valued.

- a noticeable emphasis for the origin of the bêche-de-mer products, along with the common indication that the sea cucumbers which are selling in the shops have been originated from Japan and therefore rarely recognizing the vast importance of the products from the South-East Asian region.

- a distinct liking for the size, shape and quality, causing in an extensive price series, despite within a particular species (Table 3).

\subsubsection{Price-related marketing characteristics}

system

As specified, price-behavior gives a depiction of the general market status and business target. Two critical qualities of the sea cucumber marketing structure observed that can be depended on price behavior are feasibility and reliability. Not at all like the prices of most other fishery or agriculture products, which display high seasonal changeability, have the prices of sea cucumber been steady for as far as 5 years. This is notable to bear in mind that sea cucumber harvesting to some extent is largely seasonal [57] but once the product (e.g., dried bêche-demer) is developed, it could be stored for a very longer time.

In South-East Asia, sea cucumber has yet been regarded as a minor product, and the trustworthy country-wise times-series data on market prices are lacking. Also, values depend on the species, size and quality. Mean price-data based on timeseries (i.e. mean of the different species) however basically do not have analytical values. Price behavior through time series can be determined just for similar species having a similar size and quality arrangement. An appropriate arrangement of valuable and informative data on sea cucumber prices covering the value ranges of a few species categories that traded in the Philippines between 2000 and 2007 is reported by Perez and Brown [57]. The purchasing price for the commercially harvested sea cucumber species was 3-4 times higher in 2007 than that in 2000. Such 
remarkable price increase in many countries, has been addressed to be the main reason for overfishing of sea cucumbers, particularly of the high-valued species. The reduction of sea cucumber species from the wild stock might have profound effect on the low-valued species to become medium-valued, and then the mediumvalued species to be high-valued, until many of them have been depleted to a larger extent [64]. However, this phenomenal high market values reveal the profitable essence of bêche-de-mer production and trade and more prominently, higher market prices almost warrant the profitability of increased production through aquaculture of sea cucumbers in a commercial scale [57].

\subsubsection{Marketing challenges}

Sea Cucumber has been playing a key role in the world food export and import. It is not only used as a luxury commodity in the developed countries but also acts as a staple food in some developing countries. The trade of sea cucumber is increasing day by day because of its high demand such as nutritional value as well as medicinal significance. As a result, overexploitations have recently been occurred in
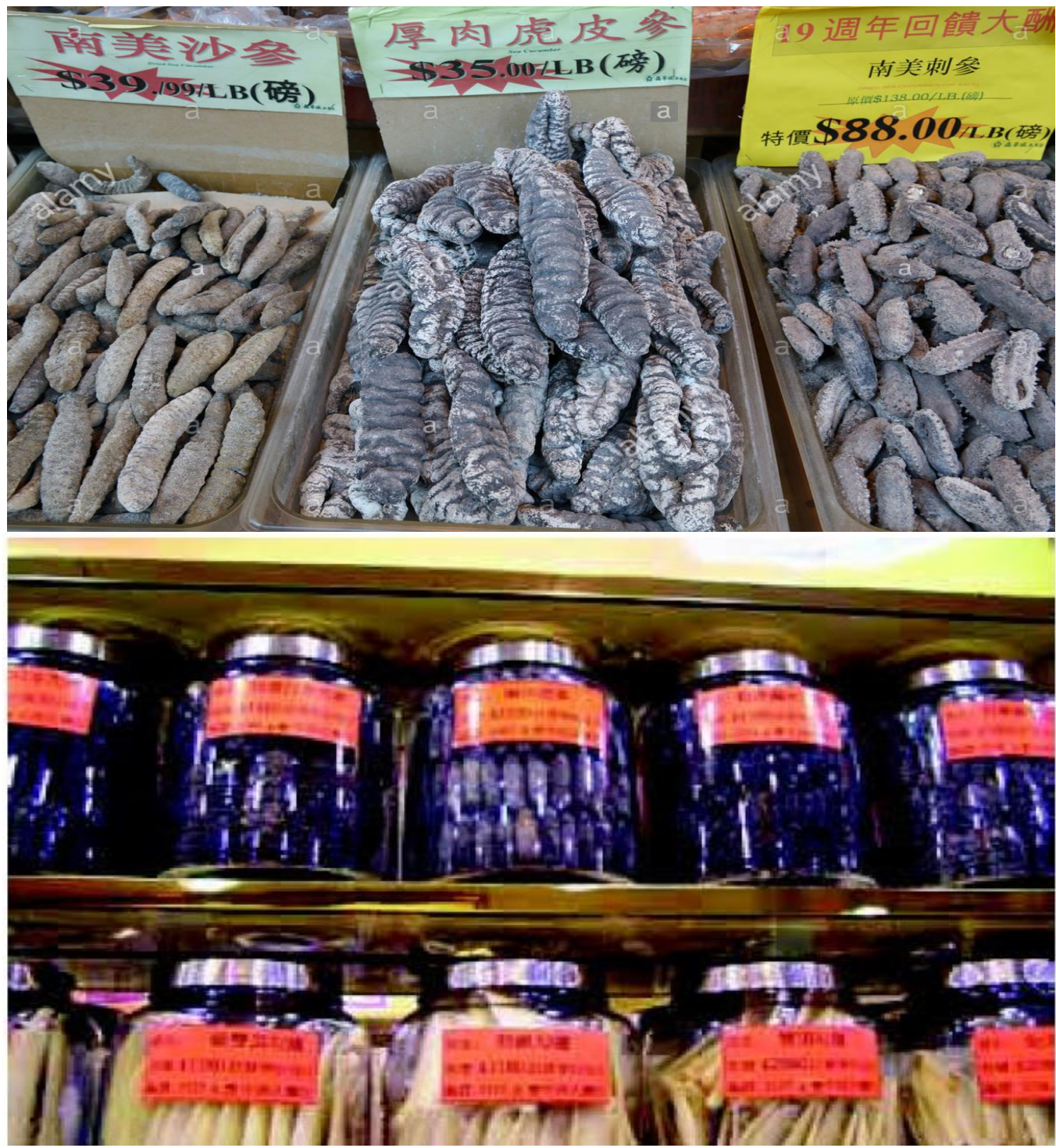

Fig. 7. Sea cucumbers on display in a herb and medicine store, Hong Kong 
Table 3. Range of retail prices for dominant sea cucumber species in South-East Asia [59]

\begin{tabular}{llll}
\hline Sea cucumber species & $\begin{array}{l}\text { Value range } \\
\text { (USD) }\end{array}$ & Sea cucumber species & $\begin{array}{l}\text { Value range } \\
\text { (USD) }\end{array}$ \\
\hline Stichopus hermanni & 62.50 & Holothuria edulis & $8.00-22.50$ \\
Stichopus chloronotus & $21.25-65.00$ & Stichopus variegatus & $6.75-62.50$ \\
Holothuria nobilis & $20.00-78.95$ & Actinopyga mauritiana & $5.00-15.00$ \\
Bohadschia argus & $20.00-30.00$ & Holothuria sp. & $4.75-44.00$ \\
Apostichopus japonicus & $17.50-112.50$ & Actinopyga echinites & $4.50-57.50$ \\
Holothuria fuscogilva & $15.50-95.00$ & Thelenota anax & $3.68-60.00$ \\
Thelenota ananas & $12.50-67.50$ & Holothuria rigida & $3.00-59.00$ \\
Holothuria scabra & $9.00-112.50$ & Holothuria impatiens & 2.50 \\
Actinopyga lecanora & $8.00-71.25$ & Holothuria atra & $1.75-22.50$ \\
Actinopyga miliaris & $8.00-44.00$ & Pearsonothuria graeffei & $1.75-5.00$ \\
Bohadschia marmorata & $1.40-23.75$ & & \\
\hline
\end{tabular}

some South Asian countries [65]. Sea cucumber is also popular for its' dry bêche-de-mer product because of the market preferences of this natural bioresource and it has been expanded to many exported market in the entire Asia. Due to the continuous overexploitation and unstrained harvesting, government must have to need some strict decision as well as undertake appropriate management strategies for sustainable sea cucumber fisheries and aquaculture. The price of sea cucumber is mainly size-depended such as the large size carries the high price and small size sells in the lowest prices [28]. Nowadays, sea cucumber production is increasing extensively in South-East Asian regions due to the application of improved Aquaculture techniques, which help to reduce the difficulties of availability of this product. The most growing country like Philippines, which is extensively selling sea cucumber in the world market because of favorable environment and the improved hatchery technology. Moreover, the supply chain system fully depended on three layers such as collector, processor and exporter but there are other extra layers including local traders and commission agents. Sometimes, extra prices are included in these products because of the handling and processing costs. Finally, the prices of sea cucumbers are increasing because of high labor cost and are also getting popularity due to high market and trade potentials. There are still some difficulties that must be addressed and solved by the SouthEast Asian countries in order to get complete profit from the enhanced sea cucumber production by implementing the improved aquaculture technology [57].

\section{CONCLUSION}

The findings emerged from the present work revealed that the sea cucumbers have not only been playing significant roles towards the fulfilment of beche-de-mer market demand but also have a vital importance for the stock enhancement and biodiversity conservation. This study also demonstrated that illegal trade might have adverse impact on sea cucumber populations and therefore, government needs to take strong initiatives to conserve high-valued sea cucumber species from extinction. Finally, government and associated organizations/departments have to urgently make significant roles towards the sustainable exploitation, proper management, effective utilization, improvement of fishers' livelihood and their socio-economic status, conservation of sea cucumber stocks, and foreign exchange earnings in commensurate with the national and international perspectives.

\section{DISCLAIMER}

The products used for this research are commonly and predominantly used products in our area of research and region. There is absolutely no conflict of interest between the authors and producers of the products because we do not intend to use these products as an avenue for any litigation but for the advancement of knowledge. Also, the research was not funded by the producing company rather it was funded by personal efforts of the authors.

\section{ETHICAL APPROVAL}

As per international standard, written ethical permission has been collected and preserved by the author(s).

\section{COMPETING INTERESTS}

Authors have declared that no competing interests exist. 


\section{REFERENCES}

1. Purcell SW. Increasing the value of sea cucumber harvests by improving postharvest processing of fishers. Working Paper 10. Presented at the SPC Heads of Fisheries Meeting, Secretariat of the Pacific Community, Noumea, New Caledonia; 2013.

2. Akamine J. The status of the sea cucumber fisheries and trade in Japan. In: Lovatelli A, Conand C, Purcell S, Uthicke S, Hamel JF, Mercier A (Eds.). Advances in sea cucumber aquaculture and management. FAO Fisheries Technical Paper, FAO, Rome. 2004;463:39-47.

3. Conand C, Byrne M. A review of recent development in the world sea cucumber fisheries. Mar Fish Rev. 1993;55(4):1-13.

4. Purcell SW. Managing sea cucumber fisheries with an ecosystem approach. In: Lovatelli A, Vasconcellos M, Yimin Y. (Eds.). FAO Fisheries and Aquaculture Technical Paper, FAO, Rome. 2010;520: 157.

5. Toral-Granda V, Lovatelli A, Vasconcellos M. Sea cucumbers: A global review of fisheries and trade. FAO Fisheries and Aquaculture Technical Paper, FAO, Rome. 2008;516:319.

6. Berkes F, Mahon R, McConney P, Pollnac $\mathrm{R}$, Pomeroy R. Managing Small-Scale Fisheries: Alternative Directions and Methods. IDRC (International Development Research Centre), Ottawa. 2001;320.

7. Conand $\mathrm{C}$. The fishery resources of Pacific island countries. Part 2: Holothurians. FAO Fisheries Technical Paper, Rome, 1990; 272(2):143.

8. Eriksson $\mathrm{H}$, Byrne $\mathrm{M}$. The sea cucumber fishery in Australia's Great Barrier Reef Marine Park follows global patterns of serial exploitation. Fish Fish. 2015;16:329_ 341.

9. FAO. FAO Yearbook of Fishery and Aquaculture Statistics 2008. FAO, Rome, Italy. 2010;72.

10. Eriksson $\mathrm{H}$, Clarke $\mathrm{S}$. Chinese market responses to overexploitation of sharks and sea cucumbers. Biol Conserv. 2015; 184:163-173.

11. Lebel L, Anderies JM, Campbell B. Governance and the capacity to manage resilience in regional social-ecological systems. Ecol Soc. 2006;11:19.

12. Andrew NL, Be'ne' C, Hall S, Allison E, Heck S, Ratner B. Diagnosis and management of small scale fisheries in developing countries. Fish Fish. 2007;8: 227-240.

13. Asha PS, Vinod K, Ranjith L, Johnson B, Vivekanandan E. Conservation and sustainable use of sea cucumber resources in India: Suggestions and way forward. CMFRI Marine Fisheries Policy Series No. 7, Central Marine Fisheries Research Institute, Kochi, India. 2017;80.

14. Rao DS, James DB, Pillai CSG, Thomas PA, Appukuttan KK, Girijavallabhan KG, Gopinathan CP, Muthuswamy S, Najmuddin M. Bioactive Compounds from Marine Organisms. Oxford and IBH Publication Co. Pvt. Ltd. 1991;367371.

15. James DB. Conservation of sea cucumbers. In: Menon NG and Pillai, C.S.G. (Eds.). Marine Biodiversity Conservation and Management. 1996; 80-88.

16. James DB, Asha PS, Ram Mohan MK, Jaiganesh $P$. Culture of sea cucumbers in shrimp farms- a takeoff in technology. In: National Seminar on Development and Transfer of Fisheries Technology. Organized by the Fisheries College and Research Institute, Tuticorin, Tamil Nadu, India. 1999;5-7.

17. James DB, Gandhi AD, Palaniswamy N, Rodrigo JX. Techniques and culture of the sea-cucumber Holothuria scabra. Central Marine Fisheries Research Institute, Kochi, India. Special Publication. 1994;57:1-40.

18. Asha PS. Reproductive aspects, larval and juvenile rearing of Holothuria (Theelothuria) spinifera Theel. PhD Thesis. Manonmaniam Sundaranar University, Tamil Nadu, India. 2005;120

19. Asha PS, Muthiah P. Effect of temperature, salinity and $\mathrm{pH}$ on the larval growth, survival and development of the commercial sea cucumber Holothuria spinifera Theel. Aquaculture. 2005;250: 823-829.

20. Pawson DL. Phylum echinodermata. In: Zhang ZQ, Shear W. (Eds.). Linnaeus Tercentenary: Progress in Invertebrate Taxonomy, volume 1668 of Zootaxa. Magnolia Press, Auckland, New Zealand. 2007;749-764.

21. Rahman MA, Yusoff FM, Arshad A. Sea cucumber fisheries: global status, culture, management and extinction risks. Int $\mathrm{J}$ Chem Environ Biol Sci. 2015;3(4):344-348. 
22. Rahman MA, Yusoff FM. Sea Cucumber fisheries: market potential, trade, utilization and challenges for expanding the production in the South-East Asia. Int $\mathrm{J}$ Adv Chem Engg Biol Sci. 2017;4(1):26-30.

23. Preston GL. Beche-de-mer. In: Wright A, Hill L. (Eds.). Nearshore Marine Resources of the South Pacific. Forum Fisheries Agency, Honiara. 1993;370.

24. Purcell S, Polidoro BA, Hamel J-F, Gamboa RU, Mercier A. The cost of being valuable: predictors of extinction risk in marine invertebrates exploited as luxury seafood. Proc R Soc Lond B Biol Sci. 2014;281:20133296.

25. Feary D, Hamilton R, Matawai M, Molai C, Karo M, Almany G. Assessing sandfish population stocks within the south coast of Manus, and a summary report of sandfish connectivity field research. Technical report of a survey conducted from May 19-June 27, 2014 Final Report. The Nature Conservancy. 2015;56

26. Anderson SC, Flemming JM, Watson R, Lotze HK. Serial exploitation of global sea cucumber fisheries. Fish Fish. 2011;12: 317-339.

27. Purcell S, Ngaluafe $P$, Karibanang $T$. Improving the income of Pacific island fisheries through better post-harvest processing of sea cucumbers: a scoping study. Australian Centre for International Agricultural Research (ACIAR), Canberra, Australia; 2012.

28. Purcell SW. Value, market preferences and trade of bêche-de-mer from Pacific Island sea cucumbers. PLoS ONE. 2014; 9(4):e95075.

29. Ferdouse F. World markets and trade flows of sea cucumber/beche-de-mer. (FAO Fisheries Technical Paper No. 463). In: Lovatelli A, Conand C, Purcell S, Uthicke S, Hamel JF, Mercier A. (Eds.). Advances in sea cucumber aquaculture and management. Food and Agriculture Organization of the United Nations, Rome. 2004;101-117.

30. Akamine J. World sea cucumber markets: Hong Kong, Guangzhou and New York. Asia-Pacific Trop Sea Cucumber Aquac. 2012;203.

31. Dee LE, Stephanie S, Daniel H, Thornhill J. Conservation and management of ornamental coral reef wildlife: Successes, shortcomings, and future directions. Biol Conserv. 2017;169:225-237.
32. Conand C, Sloan NA. World fisheries for echinoderms. In: Caddy JF. (Ed.). Marine Invertebrate Fisheries: Their Assessment and Management. Wiley Inter Science Publication, John Wiley \& Sons, New York, USA. 1989;647-663.

33. Bordbar S, Anwar F, Saari N. High-value components and bioactives from sea cucumbers for functional foods-A review. Mar Drugs. 2011;9(10):1761-1805.

34. Rahman MA. Global sea cucumber fisheries: their culture potentials, bioactive compounds and sustainable utilizations. Int J Adv Chem Engg Biol Sci. 2014a; 1(2):193-197.

35. Rahman MA. Sea cucumbers (Echinodermata: Holothuroidea): Their culture potentials, bioactive compounds and effective utilizations. In: Kao JCM, Rahman MA (Eds.). Proceedings of the International Conference on Advances in Environment, Agriculture \& Medical Sciences, International Academy of Arts, Science and Technology, Kuala Lumpur, Malaysia. 2014b;23-27.

36. Zulfaqar S, Rahman MA, Yusoff FM. Trends, prospects and utilizations of sea cucumber fisheries in Malaysia. Int $\mathrm{J} \mathrm{Adv}$ Agric Environ Engg. 2016;3(1):114-116.

37. Mondol MAM, Shin HJ, Rahman MA, Islam MT. Sea cucumber glycosides: chemical structures, producing species and important biological properties. Mar Drugs. 2017;15:317.

38. Chen J. Overview of sea cucumber farming and sea ranching practices in China. SPC Beche-de-mer Information Bulletin. 2003;18:18-23.

39. Roginsky A, Singh $B$, Ding $X z$, Collin $P$, Woodward C, Talamonti MS, Bell RH, Adrian TE. Frondanol(R)-A5p from the sea cucumber, Cucumaria frondosa induces cell cycle arrest and apoptosis in pancreatic cancer cells. Pancreas. 2004; 29:335.

40. Massin C. Effects of feeding on the environment: Holothuroidea. In: Jangoux M, Lawrence JM. (Eds.). Echinoderm Nutrition. AA Balkema, Rotterdam. 1982;493-497.

41. Hamel JF, Mercier A. Diet and feeding behavior of the sea cucumber Cucumaria frondosa in the St. Lawrence Estuary, Eastern Canada. Can J Zool. 1998;76: 1194-1198.

42. Wolkenhauer SM, Uthicke S, Burridge C, Skewes T, Pitcher R. The ecological role of Holothuria scabra (Echinodermata: 
Holothuroidea) within subtropical seagrass beds. J Mar Biol Assoc UK. 2010;90:215223.

43. Uthicke $S$. Nutrient regeneration by abundant coral reef holothurians. J Exp Mar Biol Ecol. 2001;265:153-170.

44. BOBLME. Sea cucumber conservation in Palk Bay and Gulf of Mannar - India. BOBLME-2015- Ecology-54; 2015.

45. Conand C. Sea cucumber biology, taxonomy, distribution and conservation status. In: Bruckner AW (Ed.). Proceedings of the CITES workshop on the conservation of sea cucumbers in the families Holothuriidae and Stichopodidae. NOAA Technical Memorandum USA, NMFS-OPR. 2006a;34:33-50.

46. Conand C. Reproductive biology of the holothurians from the major communities of the New Caledonian lagoon. Mar Biol. 1993;116:439-450.

47. Conand C. Harvest and trade: utilization of sea cucumbers; sea cucumber fisheries; current international trade; illegal, unreported and unregulated trade; bycatch; socio-economic characteristics of the trade in sea cucumbers. In: Bruckner AW. (Ed.). Proceedings of the CITES Workshop on the conservation of sea cucumbers in the families Holothuriidae and Stichopodidae. NOAA Technical Memorandum USA. NMFSOPR. 2006b;34: 51-73.

48. Pawiro S. Regional review on mariculture: products demand and markets. In Lovatelli A, Phillips MJ, Arthur JR, Yamamoto K. (Eds.). FAO/NACA Regional Workshop on the Future of Mariculture: A Regional Approach for Responsible Development in the Asia-Pacific Region. Guangzhou, China, 7-11 March 2006. FAO Fisheries Proceedings. No. 11. Rome. 2008;4163.

49. Conand C. Expansion of global sea cucumber fisheries buoys exports. Revista de Biología Tropical, Universidad de Costa Rica. 2017;65(Suppl.1):1-10.

50. Kinch J, Purcell S, Uthicke S, Friedman K. Papua New Guinea: A hotspot of sea cucumber fisheries in the western central pacific. Sea cucumbers: A global review of fisheries and trade. FAO Fisheries and Aquaculture Technical Paper No. 516, 2008;57-77.

51. Friedman K, Chapman L. A Regional Approach to Invertebrate Export Fisheries. Secretariat of the Pacific Community Policy
Brief 2/2008. Noumea, New Caledonia; 2008.

52. Toral-Granda V, Lovatelli A, Vasconcellos M. Sea Cucumbers: A Global Review of Fisheries and Trade. FAO Fisheries and Aquaculture Technical Paper, FAO, Rome. 2008;516.

53. Sastry DRK. Faunal diversity in India, In: Alfred JRB, Das AK, Sanyal AK. (Eds.). A commemorative volume in the 50th year of India's Independence, Zool Surv India. 1998;308-403.

54. Uthicke S, Schaffelke B, Byrne M. A boombust phylum? Ecological and evolutionary consequences of density variations in echinoderms. Ecol Monograph. 2009; 79(1):3-24.

55. Uthicke S, Benzie J. Effect of bêche-demer fishing on densities and size structure of Holothuria nobilis (Echinodermata: Holothuroidea) populations on the Great Barrier Reef. Coral Reefs. 2001;19:271276.

56. Chellaram C, Deepak V, Patterson Edward JK. Status of echinoderm fishery in the Gulf of Mannar South east coast of India. SDMRI Research Publication. 2003;3:173176.

57. Perez ML, Brown EO. Market potential and challenges for expanding the production of sea cucumber in South-East Asia. In: Hair CA, Pickering TD, Mills DJ (Eds.). AsiaPacific Tropical Sea Cucumber Aquaculture. ACIAR Proceedings 136. ACIAR, Canberra. 2012;177-188.

58. Gamboa R, Gomez A, Nievales M. The status of sea cucumber fishery and mariculture in the Philippines. University of the Philippines in Mindanao: Davao City, Philippines; 2007.

59. SEAFDEC 2009 Report of the regional study on sea cucumber fisheries, utilization and trade in Southeast Asia, 2007-2008. Secretariat, Southeast Asian Fisheries Development Center, Bangkok, Thailand. 2009;130.

60. Wiadnyana N. Sea cucumber utilization and trade in Indonesia. In: Report of the regional study on sea cucumber fisheries, utilization and trade in Southeast Asia, 2007-2008. Secretariat, Southeast Asian Fisheries Development Center, Bangkok, Thailand. 2009;30-40.

61. Ibrahim K. Sea cucumber utilization and trade in Malaysia. In: Report of the regional study on sea cucumber fisheries, 
utilization and trade in Southeast Asia, 2007-2008. Secretariat, Southeast Asian Fisheries Development Center, Bangkok, Thailand. 2009;41-62.

62. Brown E, Perez M, Garces R, Ragaza R, Bassig R, Zaragoza E. 2010. Value chain analysis for sea cucumber in the Philippines. Studies and Reviews 2120. WorldFish Center, Penang, Malaysia. 2010;44.

63. Trinidad-Roa MJ. Beche-de-mer fishery in the Philippines. Naga - the ICLARM Quarterly. October 1987;15-17.
64. Pe M. Sea cucumber utilization and trade in Myanmar. In: Report of the regional study on sea cucumber fisheries, utilization and trade in Southeast Asia, 2007-2008. Secretariat, Southeast Asian Fisheries Development Center, Bangkok, Thailand. 2009;63-67.

65. Valdimarsson G. Fish in the global food chain: challenges and opportunities. In: International seafood trade: challenges and opportunities. FAO/University of Akureyri Symposium, 1-2 February 2007, Akureyri, Iceland. 2007;17-26.

(c) 2020 Rahman et al.; This is an Open Access article distributed under the terms of the Creative Commons Attribution License (http://creativecommons.org/licenses/by/4.0), which permits unrestricted use, distribution, and reproduction in any medium, provided the original work is properly cited.

Peer-review history:

The peer review history for this paper can be accessed here: http://www.sdiarticle4.com/review-history/59418 